\title{
De invloed van computers op de vraag naar vaardigheden
}

Citation for published version (APA):

Borghans, L., \& ter Weel, B. J. (2002). De invloed van computers op de vraag naar vaardigheden. Researchcentrum voor Onderwijs en Arbeidsmarkt, Faculteit der Economische Wetenschappen. ROA Working Papers No. 001 https://doi.org/10.26481/umarow.2002001

Document status and date:

Published: 01/01/2002

DOI:

10.26481/umarow.2002001

Document Version:

Publisher's PDF, also known as Version of record

\section{Please check the document version of this publication:}

- A submitted manuscript is the version of the article upon submission and before peer-review. There can be important differences between the submitted version and the official published version of record.

People interested in the research are advised to contact the author for the final version of the publication, or visit the DOI to the publisher's website.

- The final author version and the galley proof are versions of the publication after peer review.

- The final published version features the final layout of the paper including the volume, issue and page numbers.

Link to publication

\footnotetext{
General rights rights.

- You may freely distribute the URL identifying the publication in the public portal. please follow below link for the End User Agreement:

www.umlib.nl/taverne-license

Take down policy

If you believe that this document breaches copyright please contact us at:

repository@maastrichtuniversity.nl

providing details and we will investigate your claim.
}

Copyright and moral rights for the publications made accessible in the public portal are retained by the authors and/or other copyright owners and it is a condition of accessing publications that users recognise and abide by the legal requirements associated with these

- Users may download and print one copy of any publication from the public portal for the purpose of private study or research.

- You may not further distribute the material or use it for any profit-making activity or commercial gain

If the publication is distributed under the terms of Article $25 \mathrm{fa}$ of the Dutch Copyright Act, indicated by the "Taverne" license above, 


\title{
De invloed van computers op de vraag naar vaardigheden*
}

\author{
ROA-W-2002/1
}

Lex Borghans en Bas ter Weel

* Dit onderzoek is mogelijk gemaakt door financiële steun van PROO en het algemene programma van MAGW van de Nederlandse Organisatie voor Wetenschappelijk Onderzoek (NWO). Wij danken Nic van Hal voor het verlenen van onderzoeksassistentie. Daarnaast danken wij Ronald Batenburg, Bart Diephuis, Patrick van Eijs, Andries de Grip, Hans Heijke, Hugo Hollanders, Jasper van Loo, Peter van der Meer, Christoph Meng, Ger Ramaekers, Inge Sieben en Rolf van der Velden en deelnemers aan de NWO/SISWO conferentie 'ICT en Arbeid' en een ROA-seminar voor commentaar op een eerdere versie van deze bijdrage.

\section{Researchcentrum voor Onderwijs en Arbeidsmarkt}

Faculteit der Economische Wetenschappen en Bedriffskunde Universiteit Maastricht

Maastricht, januari 2002 
ISBN 90-5321-325-2

Sec02.006.wpd 


\section{Inhoud}

Pagina

Samenvatting

i

1 Inleiding 1

2 Hoe verandert werk als gevolg van de computer? 3

2.1 Raamwerk 3

2.2 Taken 5

2.3 Vaardigheden 6

2.4 Loonkosten $\quad 8$

2.5 Implicaties $\quad 8$

3 Data en methodiek 10

4 Resultaten 12

5 Conclusies 16

$\begin{array}{ll}\text { Literatuur } & 17\end{array}$

$\begin{array}{ll}\text { Appendix A } & 21\end{array}$

$\begin{array}{ll}\text { Appendix B } & 24\end{array}$ 



\section{Samenvatting}

De introductie, implementatie en diffusie van de computer in zijn vele verschijningsvormen heeft het karakter van veel werkzaamheden veranderd. Tevens hebben verschuivingen plaatsgevonden in de vaardigheden die voor het werk van belang zijn. Dit heeft in een groot aantal gevallen geleid tot een verhoging van de opleidingseisen die door werkgevers worden gesteld. Om een goed beeld te krijgen van de implicaties van de opkomst van de computer, analyseren we hoe de computer het werk verandert en welke vaardigheden in belang zijn toegenomen. Dit gebeurt aan de hand van de vraag hoe het werk verandert wanneer iemand een computer krijgt. De analyses worden geillustreerd aan de hand van empirische gegevens van hooggeschoolde schoolverlaters uit 64 regio's in 11 Europese landen. Uit deze analyses komt naar voren dat de opkomst van de computer heeft geleid tot een toenemende arbeidsmarktwaarde van algemene kennis, plannen, coördineren en organiseren, economisch denken, analytische vaardigheden, mondelinge communicatievaardigheden en de bereidheid verantwoordelijkheid te nemen. Er zijn geen aanwijzingen dat meer aandacht geschonken zou moeten worden aan computervaardigheden. Opmerkelijker is wellicht dat in tegenstelling tot wat vaak wordt aangenomen het belang van interdisciplinaire kennis, probleemoplossend vermogen, accuratesse en oog voor details en leiderschap lager wordt naarmate de computer verder zijn intrede doet. Ook het belang van leervermogen neemt eerder af dan toe. Het valt overigens te verwachten dat deze balans voor verschillende beroepen verschillend uitpakt en dat deze ontwikkelingen op de markt voor hoger opgeleiden niet vanzelfsprekend voor middelbare of lager opgeleide werknemers hoeven te gelden. Omdat uit de analyses blijkt dat de computer ten eerste zeer aanzienlijke invloed op de waarde van kennis heeft, en het ten tweede moeilijk is deze implicaties op voorhand te overzien, is zorgvuldig meten en analyseren van de ontwikkelingen in verschillende beroepsgroepen van cruciaal belang, om in het onderwijs- en arbeidsmarktbeleid goed in te kunnen spelen op een dynamische arbeidsmarkt. 


\section{Inleiding}

De introductie van computers op de werkplek is waarschijnlijk de meest radicale verandering van het werk geweest in de afgelopen decennia. Sinds de jaren zeventig zijn door de uitvinding van de microchip vele applicaties ontwikkeld die het mogelijk hebben gemaakt delen van het werk te automatiseren. Het computergebruik op het werk is dan ook sterk toegenomen. In de Verenigde Staten is het computergebruik in de periode 1984-1997 meer dan verdubbeld van 24.3 naar 52.5 procent (zie bijvoorbeeld, Autor, Katz en Krueger, 1998). In EU landen is een vergelijkbare trend waarneembaar: in 1996 gebruikte meer dan de helft van de werknemers een computer op het werk (zie bijvoorbeeld, Smulders, 2000). Er zijn duidelijke aanwijzingen dat de opkomst van de computer heeft geleid tot een substantiële verandering van het werk en een verhoging van de opleidingseisen ${ }^{1}$. Een groot aantal studies op zowel bedrijfsniveau als voor de arbeidsmarkt als geheel rapporteren een positieve correlatie tussen de upgrading van de opleidingseisen en de toename van computergebruik ${ }^{2}$. Onderzoek heeft echter inmiddels duidelijk gemaakt dat het te eenvoudig is om aan te nemen dat de kennis en vaardigheden die nodig zijn om te kunnen werken met een computer deze upgrading verklaren. Doordat computers bepaalde werkzaamheden automatiseren, nemen juist de werkzaamheden die niet gecomputeriseerd (kunnen) worden in belang toe. Daarnaast zullen werkgevers inspelen op de mogelijkheden die een computer biedt en verandert de aard van de producten maar ook de optimale organisatiestructuur binnen een bedrijf (zie bijvoorbeeld Borghans en Ter Weel, 2001c, Bresnahan, Brynjolfsson en Hitt, 2001 en Caroli en Van Reenen, 2001). Al deze veranderingen hebben invloed op de waarde van bepaalde vormen van kennis en vaardigheden op de arbeidsmarkt en beïnvloeden het optimale opleidingsniveau voor verschillende beroepen. Hoewel uit eerder onderzoek is gebleken dat de directe invloed van computers op de kwalificaties die gesteld worden aan werknemers gering is, lijken de indirecte implicaties relatief omvangrijk te zijn.

In deze bijdrage analyseren we hoe de computer (in al zijn verschijningsvormen) de arbeidsmarkt heeft veranderd en welke implicaties dit heeft voor de waarde van verschillende soorten vaardigheden en voor de vraag naar hoger opgeleiden. Aan de hand van een theoretisch kader brengen we in kaart op welke wijze de introductie van de computer de vraag naar arbeid kan beïnvloeden. Op basis van een empirische analyse van hooggeschoolde schoolverlaters in 64 regio's in 11 Europese landen laten we vervolgens zien welke

1. Autor, Katz en Krueger (1998) vinden dat de groei van de gemiddelde investeringen in computers van 0,026 in de jaren zeventig naar 0,057 in de jaren tachtig ongeveer 36 procent van de upgrading binnen de industriële sectoren van de Verenigde Staten kan verklaren.

2. Zie bijvoorbeeld Groot en De Grip (1991), Levy en Murnane (1996), Autor, Levy en Murnane (2000) en Fernandez (2001) voor bedrijfsspecifieke case studies; Krueger (1993), Berman, Bound en Griliches (1994), Dunne en Schmitz (1995), Chennells en Van Reenen (1997), DiNardo en Pischke (1997), Doms, Dunne en Troske (1997), Entorf en Kramarz (1997), Miller en Mulvey (1997), Autor, Katz en Krueger (1998), Berman, Bound en Machin (1998), Machin en Van Reenen (1998), Katz en Autor (1999), Dunne, Foster, Haltiwanger en Troske (2000), Borghans en Ter Weel (2001b) en Lang (2001) voor studies met bredere implicaties van computerintroductie. 
vaardigheden toenemen als gevolg van computergebruik en welke vaardigheden juist minder belangrijk worden.

Het perspectief dat we in deze analyse hanteren is dat de computer mensen ondersteunt in hun werk. De aard van de ondersteuning en de aard van het werk kan hierbij sterk uiteenlopen. In de economische literatuur is het gebruikelijk om de computer te zien als een productiemiddel dat vraagt om werknemers die in staat zijn de mogelijkheden van deze machine efficiënt te benutten. Vanuit dit oogpunt werd lang de nadruk gelegd op het belang van computervaardigheid of op zogenaamde complementaire vaardigheden die het werken met de computer aanvulden en op die manier de potentie van de computer ten volle realiseerden. Vanuit het ondersteuningsperspectief is het van belang op te merken dat mensen in hun werk veelal een aantal uiteenlopende taken hebben. De computer is in staat sommige taken over te nemen, terwijl andere taken (nog) niet kunnen worden geautomatiseerd. Doordat na computerisering van (een deel van) het werk meer nadruk komt te liggen op de taken die niet zijn geautomatiseerd, zal ook de waarde van vaardigheden die nodig zijn om deze taken goed te kunnen vervullen toenemen. Om welke taken het hierbij gaat hangt echter af van de toevallige functie waarin iemand werkzaam is en kan dus sterk verschillen van beroep tot beroep. Deze uiteenlopende veranderingen per beroep, samen met verschuivingen in organisatievormen en producten, die het indirecte gevolg zijn van de opkomst van de computer, zullen echter ook de marktwaarde van vaardigheden in het algemeen veranderen.

Op basis van een vergelijking van de waarde van vaardigheden in 64 regio's in Europa die verschillen in de mate waarin ze zijn gecomputeriseerd, brengen we in deze bijdrage de veranderingen in de vraag naar vaardigheden als gevolg van de computer in beeld. Uit onze analyses komt naar voren dat de opkomst van de computer heeft geleid tot een toenemende arbeidsmarktwaarde van algemene kennis, plannen, coördineren en organiseren, economisch denken, analytische vaardigheden, mondelinge communicatievaardigheden en de bereidheid verantwoordelijkheid te nemen. Er zijn geen aanwijzingen dat meer aandacht geschonken zou moeten worden aan het aanleren van computervaardigheden of dat computervaardigheden in belang zullen toenemen. Opmerkelijker is wellicht ! en in tegenstelling tot wat vaak wordt aangenomen! dat het belang van interdisciplinaire kennis, probleemoplossend vermogen, accuratesse en oog voor details en leiderschap lager wordt naarmate de computer verder zijn intrede doet. Ook het belang van leervermogen neemt eerder af dan toe.

De bevindingen tonen aan dat de diffusie van de computer tot grote verschuivingen in het belang van bepaalde vaardigheden kan leiden. De aard van deze verschuivingen komt in een aantal gevallen overeen met wat veelal wordt gedacht, maar blijkt in andere gevallen sterk af te wijken van de heersende denkbeelden. Omdat verder duidelijk is dat de implicaties van de verdere digitalisering van werk sterk kunnen verschillen tussen beroepen en opleidingsniveau's is de belangrijkste implicatie van deze bijdrage dat het van groot belang is deze ontwikkelingen op de arbeidsmarkt beter in kaart te brengen. 
Deze bijdrage is als volgt georganiseerd. Eerst presenteren we een theoretisch kader dat inzicht geeft in de veranderingen op het werk als gevolg van de introductie van de computer. Vervolgens bespreken we kort de data die we gebruiken om verschuivingen in de waarde van vaardigheden in kaart te brengen en gaan we in op de gevolgde schattingsmethode. Daarna rapporteren en bespreken we de empirische resultaten. We eindigen met een conclusie en enkele beleidsimplicaties.

\section{Hoe verandert werk als gevolg van de computer?}

Een essentieel kenmerk van computers is dat ze werknemers ondersteunen bij het uitvoeren van hun werkzaamheden ${ }^{3}$. De computer bevindt zich dan ook vaak in de buurt van iemands werkplek: de PC met internettoegang staat op het bureau van de manager, de computerkassa staat op de toonbank van bijna iedere winkel, het Global Positioning System (GPS) is een belangrijke ondersteuning voor de moderne vrachtwagenchauffeur, de tandarts heeft een bestand van ieders gebit die steeds wordt aangepast aan de laatste stand van zaken na de halfjaarlijkse controle, en de lasser gebruikt een infrarood technologie die zijn las op een beeldscherm weergeeft, zodat hij de las kan controleren op eventuele zwakke plekken. Wanneer wij deze bijdrage schrijven werken we ook een groot deel van de tijd met onze PC's, maar de samenwerking met die computer blijft beperkt. De computer houdt bij welke woorden we reeds aan het verhaal hebben toegevoegd, is behulpzaam bij het schuiven met alinea's, het corrigeren van de spelling, het e-mailen van de tekst naar elkaar en het uitvoeren van commando's om regressie analyses uit te voeren. Een groot deel van het proces nadenken over de boodschap en de inhoud van de bijdrage en het interpreteren van de implicaties van de regressieresultaten - blijft echter arbeid die we zelf uitvoeren en waartoe de computer niet in staat is.

\subsection{Raamwerk}

In het algemeen ondersteunt de computer de werknemer door sommige taken over te nemen, wat leidt tot een efficiëntere manier van produceren zonder dat de computer al het werk overneemt en de werknemer eigenlijk overbodig wordt. Om de invloed van computers op de manier waarop mensen werken te bepalen en te verklaren wanneer een computer

3. Deze zienswijze werd niet altijd gedeeld. In de jaren zestig en zeventig werd de computer vooral gezien als een apparaat dat werk van mensen overnam en efficiënter uitvoerde. De eerste computergestuurde robots lasten, spoten en construeerden auto's die eerst door mensenhanden in elkaar werden gezet; computers namen administratieve werkzaamheden van boekhouders over; en computers namen in de procesindustrie op basis van meetgegevens uit de fabriek zelfstandig beslissingen over de voortgang van het productieproces. Het beeld bestond dat de computer steeds meer werk zou overnemen van de mens. In de toekomst zou waarschijnlijk ook de vertaler plaats moeten maken voor een vertaalcomputer. Onder veel economen, maar vooral onder de bevolking, bestond dan ook de vrees dat de computer en later informatie en communicatietechnologie (ICT) veel werk van de mensen zou overnemen en dat grote groepen van de bevolking werkloos zouden worden. Zie onder andere Freeman en Soete (1994) voor een overzicht. 
wordt ingezet om bepaalde activiteiten te ondersteunen, is het van belang op structurele wijze te kijken naar de manier waarop computers worden gebruikt op het werk. Om tot een eenvoudig raamwerk te komen, onderscheiden we drie verschillende activiteiten binnen een baan ${ }^{4}$. Ten eerste zijn er taken die een werknemer moet uitvoeren, maar die worden overgenomen door de computer als deze wordt geïmplementeerd op de werkplek. Ten tweede zijn er taken die ook na de introductie van de computer op het werk door de werknemer zelf worden uitgevoerd. Tenslotte is het mogelijk dat na de introductie van de computer een aantal nieuwe taken ontstaan die gerelateerd zijn aan het bedienen van de computer ${ }^{5}$. Waarschijnlijk bestaan deze drie verschillende activiteiten binnen een baan uit taken die sterk aan elkaar gerelateerd zijn. Bijvoorbeeld, het nadenken over een tekst en het opschrijven ervan zijn gecombineerde activiteiten, maar wanneer de typemachine wordt vervangen door een PC met tekstverwerker blijt het nadenken over de tekst ongewijzigd, terwijl het typen ervan veel eenvoudiger en efficiënter is geworden (na iedere typefout hoeft namelijk niet een nieuw vel te worden genomen) ${ }^{6}$. Sommige auteurs hebben aangegeven dat de computer ook de taken verandert die niet worden overgenomen door de computer. Vanwege het feit dat het verwerken van informatie en het communiceren met andere werknemers steeds goedkoper is geworden, is het mogelijk dat bedrijven hun organisatiestructuur veranderen, de producten die ze produceren aanpassen en de wijze waarop producten worden geproduceerd zodanig wijzigen dat de mogelijkheden die computertechnologie biedt zo optimaal mogelijk worden uitgebuit. Het is dus waarschijnlijk dat deze veranderingen ook het niet- gecomputeriseerde deel van het werk veranderen ${ }^{7}$.

Wanneer we veronderstellen dat een baan bestaat uit een set taken die bepaalde vaardigheden vereisen, kunnen we een concept ontwikkelen dat inzicht geeft in hoe de computer de configuratie van een bepaalde baan (en wellicht de arbeidsmarkt als geheel) verandert door middel van een verschuiving van het belang van taken, de vaardigheden en de benodigde tijd voor het uitvoeren van bepaalde taken binnen een baan. Uiteraard neemt iedere taak die een werknemer moet uitvoeren enige tijd in beslag en de tijd die nodig is een bepaald aspect van een baan uit te voeren, hangt waarschijnlijk samen met de vaardigheden van deze werknemer. Sommige vaardigheden kunnen gerelateerd zijn aan het uitvoeren van alle taken binnen een baan, terwijl andere, meer specifieke vaardigheden, waarschijnlijk slechts

4. Zie Borghans en Ter Weel (2001a) voor een meer formele uitwerking van dit raamwerk. Autor, Levy en Murnane (2001) ontwikkelen een model langs vergelijkbare lijnen.

5. Deze effecten die de introductie van de computer met zich meebrengt, komen overeen met de bevindingen van Autor, Levy en Murnane (2001). Zij vinden dat de computer een klein aantal taken overneemt, die veelal routinematig en eenvoudig zijn en dat de computer niet-routinematige taken en probleemoplossend vermogen in een baan ondersteunt en wellicht belangrijker maken.

6. Hoewel de kenmerken en de vaardigheden die nodig zijn om deze twee taken uit te voeren erg van elkaar verschillen, veronderstellen we dat de nauwe relatie tussen deze taken het onmogelijk maakt de taken te scheiden in twee verschillende banen. Als dit wel mogelijk is, zou waarschijnlijk een erg goede denker worden gecombineerd met iemand die erg goed kan typen.

7. Zie voor een nadere uitwerking van dit soort argumenten bijvoorbeeld Lindbeck en Snower (2000), Borghans en Ter Weel (2001c), Bresnahan, Brynjolfsson en Hitt (2001) en Caroli en Van Reenen (2001). 
bepalend zijn voor de efficiency van het uitvoeren van een klein gedeelte van het werk. Het zou bijvoorbeeld zo kunnen zijn dat werknemers met meer scholing (en meer vaardigheden) iedere taak sneller kunnen uitvoeren dan werknemers met minder scholing (zowel voor als na de introductie van de computer), terwijl een serveerster met zeer goede communicatieve vaardigheden erg goed klanten kan bedienen, maar niet beter is in het afhandelen van bestellingen wanneer zij op het terras een computergestuurde bestellijst moet bedienen.

Naar aanleiding van dit takenconcept van een baan kunnen we de introductie van een computer interpreteren als de beslissing van een bedrijf, dat de kosten van de aanschaf van een computer(systeem) tegenover de baten plaatst. Deze beslissing wordt gebaseerd op een break-even-punt waarop de winst van het bedrijf hetzelfde blijft onafhankelijk van de introductie van een computer. Een bedrijf zal slechts overgaan tot de aanschaf van computers wanneer de kosten die moeten worden gemaakt lager zijn dan de baten van de tijdwinst die wordt geboekt. Dit komt overeen met het wegen van hogere kosten voor de configuratie van de baan (die nu ook computerkosten met zich meebrengt) ten opzichte van de verhoogde productiviteit die resulteert als gevolg van de tijdwinst (die de werknemer in staat stelt meer eenheden output te produceren in dezelfde hoeveelheid tijd). Behalve op basis van de kosten die de aanschaf van een computer(systeem) met zich meebrengt (en wellicht de computercursus voor de werknemer) is de beslissing een werknemer te laten werken met een computer gebaseerd op de volgende drie afwegingen die zijn gerelateerd aan de productiviteitswinst die een werknemer boekt door te werken met een computer: (i) het belang van de taken die binnen een baan kunnen worden gecomputeriseerd, (ii) de vaardigheden van de werknemer, en (iii) het loon dat de werkgever moet betalen of de loonkosten die de werkgever kan besparen door een efficiëntere wijze van productie wanneer de computer is geïntroduceerd.

Laten we deze drie afwegingen één voor één nader bespreken.

\subsection{Taken}

Het lijkt triviaal dat de computer wordt geïntroduceerd wanneer er taken zijn die kunnen worden gecomputeriseerd. Het heeft immers geen zin een houthakker van een computer te voorzien en dan de impact op zijn arbeidsmarktpositie te meten. Zo'n exercitie zou even zinloos zijn als het meten van de invloed van een motorzaag op de arbeidsmarktpositie van een econoom. Echter, de meeste banen hebben taken die routinematig zijn en die in principe zouden kunnen worden gecomputeriseerd ${ }^{8}$ Een voorbeeld van zo'n baan is de opticien die klanten helpt en adviseert bij de aanschaf van brillen en zonnebrillen. Het is van belang dat de

8. Uiteraard is de grens tussen de taken die op een gegeven moment kunnen worden gecomputeriseerd en de taken die niet kunnen worden gecomputeriseerd vaag. Grote investeringen en de inzet van vele programmeurs zouden er immers toe kunnen leiden dat ook taken die gewoonlijk niet gecomputeriseerd kunnen worden nu wel door een computer kunnen worden uitgevoerd. Hier veronderstellen we echter dat er een scherpe grens bestaat tussen de taken die wel en de taken die niet kunnen worden gecomputeriseerd. 
opticien bij het repareren, snijden en monteren van de glazen heel nauwkeurig en zorgvuldig te werk gaat. Daarnaast moet de opticien goed en geduldig naar de wensen van de klant kunnen luisteren om aan zijn eisen te kunnen voldoen en de goede bril te adviseren. Een ander voorbeeld is de redactiechef. Hij moet gegevens bijhouden en verwerken die de inhoud van een krant, tijdschrift of programma voor radio of televisie bepalen. Tevens is het van belang dat de redactiechef leiding kan geven en mensen kan inspireren om zo goed mogelijk te functioneren en samen te werken in het redactieteam. In het geval van de opticien is het slijpen van glazen een routinematige bezigheid, terwijl het destilleren van de wensen van de klant op elk moment verschillend is en veel aandacht vraagt. Ook in het geval van de redactiechef gaat deze redenering op, want het sorteren van binnengekomen informatie is een aspect van het werk dat gebaseerd is op routine. Het scherp houden van de redactie en het bevorderen van de samenwerking en teamgeest zijn echter aspecten van het werk die veeleer een specifieke en telkens andere aanpak vereisen.

Uit eerder onderzoek is inderdaad gebleken dat bepaalde taken zich beter lenen voor automatisering dan anderen. Autor, Levy en Murnane (2001) delen werk op in taken die beschreven kunnen worden als logische stappen in een "als-dan-redenering" en meer intuïtieve en niet- routinematige werkzaamheden waarbij dit niet mogelijk is. Het blijkt dat een computer vooral de eerste groep werkzaamheden overneemt. Deze werkzaamheden zijn overigens op verschillende werkniveau's te vinden. Borghans en Ter Weel (2001b) laten zien dat werknemers in banen waar lezen en rekenen (zowel eenvoudige berekeningen als complexe wiskundige problemen) van belang zijn, een grotere kans op het werken met een computer hebben.

\subsection{Vaardigheden}

De computer leidt tot een efficiëntere wijze van productie. Deze nieuwe productiewijze vraagt minder arbeid gegeven het aantal eenheden product dat wordt geproduceerd. De tijdwinst in het productieproces hangt af van het specifieke karakter van de taken, maar ook van de vaardigheden van de werknemer. Het deel van de tijdwinst dat resulteert vanwege het uitvoeren van specifieke taken reflecteert waarschijnlijk de ontwikkeling van nieuwe en meer efficiënte applicaties, software en hardware ${ }^{9}$. Met betrekking tot de vaardigheden van de werknemer valt te verwachten dat degene die na de introductie van de computer efficiënter produceert over meer vaardigheden beschikt dan degene die minder efficiënt produceert na de introductie van de computer. Dit is het geval omdat (i) de tijd die nodig is om een eenheid product te produceren wordt gereduceerd met de tijd die nodig is om de gecomputeriseerde taken uit te voeren, (ii) de productietijd toeneemt als gevolg van het bedienen van de

9. Greenwood en Yorukoglu (1997) laten zien dat de prijs van computers dramatisch is gedaald sinds het begin van de jaren zeventig en dat de investeringen in informatie technologie als percentage van de totale kapitaal investeringen zijn gestegen van zo'n 10 procent in 1970 tot ongeveer 40 procent in 1990. Deze prijsdaling heeft uiteraard bijgedragen aan de verspreiding van computers, omdat het voor werkgevers steeds interessanter wordt computers in te zetten. Jorgenson (2001) toont vergelijkbare cijfers voor de Verenigde Staten en EITO (2000) geeft een overzicht van de prijsdaling van processoren die worden gebruikt in onder andere PC's. 
computer, en (iii) de productietijd ook kan veranderen omdat de computer invloed kan hebben op het niet-gecomputeriseerde deel van het werk. Vanuit een vaardighedenperspectief geredeneerd kan daarom worden gesteld dat de computer het meest efficiënt kan worden ingezet in banen waarin werknemers over relatief lage vaardigheden beschikken met betrekking tot de taken die worden gecomputeriseerd en over relatief hoge vaardigheden beschikken in het niet-gecomputeriseerde deel van het werk. Deze relatie tussen de tijdwinst als gevolg van de computer en de vaardigheden van werknemers kan worden gedefinieerd als de "skill bias" van de adoptie van nieuwe technologie, omdat de vaardigheden (i) gerelateerd zijn aan het uitvoeren van de gecomputeriseerde taak of (ii) aan de andere nietgecomputeriseerde en niet-routinematige taken. Dit leidt ertoe dat als het werk met een computer hogere eisen stelt aan de benodigde vaardigheden, hooggeschoolde werknemers een relatief voordeel hebben, wat zou kunnen leiden tot een hoger computergebruik onder hooggeschoolden.

Deze redenering die de vaardigheden centraal stelt, roept echter enkele vragen op. Ten eerste is er geen reden waarom een werkgever het werk van relatief hooggeschoolde werknemers computeriseert wanneer deze werknemers iedere taak sneller kunnen uitvoeren omdat ze er beter in zijn. Het is namelijk de relatieve tijdwinst die bepaalt wanneer de computer wordt geïntroduceerd. Ten tweede hebben werknemers die beter zijn in het uitvoeren van de niet-routinematige activiteiten geen grotere kans een computer te gebruiken, omdat het niet per definitie zo is dat het niet-routinematige deel van het werk ook sneller kan worden uitgevoerd. Tenslotte zijn erg grote verschillen in computervaardigheid tussen werknemers waarschijnlijk geen reden om de computer te geven aan mensen met een betere computervaardigheid, omdat het deel van het werk dat wordt gecomputeriseerd vaak slechts een klein deel van de totale werkzaamheden vormt ${ }^{10}$.

Het belangrijkste probleem van het vaardighedenperspectief is wellicht dat er geen directe relatie bestaat tussen de vaardigheden die iemand heeft en het werken met een computer. Uit Engelse $^{11}$ en Duitse ${ }^{12}$ gegevens blijkt dat computervaardigheden er niet toe lijken te doen op de arbeidsmarkt: zij worden niet beloond door de werkgever. Ook komt uit onderzoek naar voren dat andere vaardigheden de kans op computergebruik niet lijken te beïnvloeden. Interessant in dit opzicht is de literatuur die zich richt op computergebruik onder ouderen. In tegenstelling tot wat vaak wordt aangenomen blijkt computergebruik in de leeftijdsgroep 35-50 hoger te zijn dan onder jongeren. Er zijn inmiddels verschillende interessante verklaringen aangedragen voor dit opmerkelijke leeftijdsprofiel. Wat uit deze discussie in ieder geval

10. Deze bevinding komt overeen met de observaties van Levy en Murnane (1996) voor een grote bank in de Verenigde Staten. Hun bevindingen tonen aan dat de routinematige taken die werden geautomatiseerd na de introductie van de computer slechts een klein deel van de werkzaamheden betrof, terwijl het belang van de niet- routinematige werkzaamheden steeg na de introductie van computers. Fernandez (2001) observeert vergelijkbare veranderingen in een grote chocoladefabriek die werd omgebouwd vanwege een nieuwe computergestuurde productietechnologie.

11. Zie Bell (1996) en Borghans en Ter Weel (2001b).

12. Zie DiNardo en Pischke (1996) en Borghans en Ter Weel (2001e). 
duidelijk is geworden, is dat de verschillen in vaardigheden tussen de leeftijdscohorten er veel minder toe doen dan vaak werd gedacht ${ }^{13}$.

\subsection{Loonkosten}

Tenslotte hangt de derde afweging die de werkgever maakt om wel of niet een computer te introduceren samen met het loonniveau van de werknemers. Een bedrijf dat gemiddeld hogere lonen betaald dan een ander bedrijf is waarschijnlijk eerder geneigd computers te implementeren, omdat het relatief gezien meer loonkosten kan besparen: als de lonen relatief hoog zijn, gegeven de te computeriseren taken en de vaardigheden van het werknemersbestand, zal een computer eerder rendabel zijn, omdat het een efficiënter productieproces genereert waarin met minder gewerkte uren dezelfde productie kan worden gehaald. Dit argument bevestigt de bevindingen van Doms, Dunne en Troske (1997) gebaseerd op een panel van bedrijven in de Verenigde Staten, de resultaten van Entorf en Kramarz (1997) gebaseerd op individuele werknemers in Frankrijk en de resultaten van Chennells en Van Reenen (1997) gebaseerd op schattingen met instrumentele variabelen voor het Verenigd Koninkrijk waarin het loon en de technologiekeuze simultaan worden geschat. Deze drie studies vinden dat bedrijven die relatief hogere lonen betalen eerder computers implementeren in het productieproces dan bedrijven die relatief lagere lonen uitkeren. Dit leidt ertoe dat het niveau van de lonen waarschijnlijk een belangrijke determinant van computergebruik is, wat suggereert dat relatief hogere lonen leiden tot een toenemend gebruik van computers en niet dat hogere lonen het gevolg zijn van computergebruik. Deze bevindingen komen overeen met de resultaten van vele empirische studies die de computerisering van de arbeidsmarkt onderzoeken en vinden dat computergebruikers een hoger loon ontvangen. Deze empirische studies interpreteren de hogere lonen echter vooral als een soort premie op computergebruik of computervaardigheden, terwijl de analyses hierboven het omgekeerde voorspellen. Borghans en Ter Weel (2001a) laten zien dat een hoger loon inderdaad tot een hogere kans op computergebruik leidt en dat het (loon)kostenargument los van overwegingen over vaardigheden een belangrijke determinant van computergebruik is.

\subsection{Implicaties}

Belangrijke consequentie van dit raamwerk is dat een computer niet per sé als eerste wordt geïntroduceerd bij mensen die qua vaardigheden hiervoor het meest geschikt zijn. Uit de constatering dat de eerste gebruikers van computers vooral mensen waren voor wie communiceren en informatieverwerking belangrijke aspecten van het werk zijn, kan niet worden geconcludeerd dat deze elementen voor iedereen belangrijk worden als de computer verder zijn intrede doet. Als de kosten-baten-afweging positief uitvalt en er inderdaad een computer wordt geïntroduceerd op het werk worden de taken die niet zijn gecomputeriseerd belangrijker. Welke taken dit zijn kan verschillen van beroep tot beroep. Omdat een groot

13. Zie onder andere Bartel en Sicherman (1993), Ahituv en Zeira (2001), Borghans en Ter Weel (2001d), Friedberg (2001) en Weinberg (2001). 
aantal vaardigheden zowel betekenis kan hebben voor computeriseerbare als voor nietcomputeriseerbare taken is het totale effect van deze verschuivingen moeilijk in te schatten op theoretische gronden. Een voorbeeld hiervan is de waarde van leervermogen. Juist omdat door de computer het werk steeds minder routinematig wordt, is vaak gewezen op het belang van leervermogen en de noodzaak van levenslang leren. Echter een groot deel van wat mensen leren tijdens hun beroepsloopbaan heeft betrekking op routinematige zaken. De juiste spelling van een woord, de precieze regels en percentages van een belastingwet, de prijzen van de producten in de winkel etc., moesten mensen vroeger leren en onthouden, terwijl met de introductie van de computer dergelijke kennis niet meer nodig is. Juist omdat dit soort feitenkennis snel veroudert valt een deel van de noodzaak om voortdurend bij te leren dus weg.

Daarnaast kan de introductie van de computer ook indirect effecten hebben op de waarde van vaardigheden ${ }^{14}$. Door veranderingen in de productiviteit van verschillende functies en omdat de prijs van de betreffende goederen zal veranderen, zal ook de vraag naar arbeid in verschillende beroepen verschuiven. Tevens is uit onderzoek duidelijk geworden dat bedrijven hun producten aanpassen aan de mogelijkheden die de computer biedt. Ook de optimale organisatiestructuur blijkt te veranderen door de introductie van de computer. In het algemeen blijken organisaties platter te worden. Hiërarchische verhoudingen worden minder belangrijk, terwijl professionele communicatie tussen mensen op gelijk niveau in belang toeneemt (zie bijvoorbeeld Lindbeck en Snower, 2000).

Op het moment dat de computer in bepaalde beroepen wordt geïntroduceerd zal de waarde van vaardigheden daarom verschuiven. De beslissing computers te introduceren op de werkplek zal afhangen van de kosten en baten van computergebruik. Vanwege de dalende kosten van computerhardware en -software zullen meer en meer werknemers gebruik maken van computers op het werk. Omdat er ook gecorrigeerd voor opleidingsniveau aanzienlijke loonsverschillen tussen landen en regio's bestaan, zal het moment waarop bepaalde groepen een computer krijgen dus waarschijnlijk verschillen.

Deze veranderingen in het belang van vaardigheden hebben implicaties op twee niveau's. Allereerst zal het leiden tot veranderingen in de vaardigheden die van belang zijn in specifieke banen als daar de computer wordt geïntroduceerd. Om het curriculum adequaat aan te passen aan de nieuwe eisen die het werk stelt, lijken dergelijke analyses uiteraard van groot belang. Omdat de niet-gecomputeriseerde taken in elk beroep waarschijnlijk anders zijn, zouden ook deze verschuivingen van beroep tot beroep sterk kunnen verschillen. Daarnaast zal als gevolg van deze verschuivingen binnen ieder beroep ! en de verschuivende vraag naar arbeid tussen deze beroepen ! ook de waarde van verschillende vaardigheden op de arbeidsmarkt veranderen. In deze bijdrage richten we ons met name op marktverschuivingen. De algemene tendensen die uit een dergelijke analyse naar voren komen impliceren en voorspellen echter geenszins dat in ieder beroep dezelfde verschuivingen op zullen treden.

14. Zie Borghans en Ter Weel (2001a) voor een overzicht. 
Het ligt het meest voor de hand om voor een dergelijke analyse van het verschuivende belang van vaardigheden te kijken naar veranderingen in de waarde van vaardigheden in de tijd. Probleem hierbij is allereerst dat er nog nauwelijks adequate data voorhanden is waarin de vaardigheden van werkenden in beeld wordt gebracht. Een lange tijdreeks van dergelijke data is dus helaas niet beschikbaar. Daarnaast is het in een tijdreeks analyse vrijwel onmogelijk de invloed van computergebruik te scheiden van andere veranderingen die in de loop der tijd de waarde van vaardigheden beïnvloeden. Om die reden analyseren we in deze bijdrage verschillen in de waarde van vaardigheden tussen regio's. Door de waarde van de vaardigheden in deze regio's te relateren aan het computergebruik in deze regio's kan een beeld verkregen worden van de invloed van toenemend computergebruik. Teneinde een goed beeld van deze mogelijke verschuiving te krijgen, onderzoeken we de arbeidsmarktpositie van een relatief homogene groep van hoger opgeleide schoolverlaters uit 64 regio's in 11 Europese landen.

\section{Data en methodiek}

De data die we gebruiken bestaat uit informatie over pas afgestudeerden uit het hoger onderwijs (in Nederland academici en HBO'ers) uit 11 Europese landen. Deze data zijn afkomstig uit het project Higher Education and Graduate Employment in Europe (CHEERS) dat werd uitgevoerd in 1999. De enquête werd gehouden in de EU lidstaten Duitsland, Finland, Frankrijk, Italië, Nederland, Oostenrijk, Spanje, het Verenigd Koninkrijk en Zweden en daarnaast in Japan, Noorwegen en Tsjechië. Vanwege grote cultuurverschillen en andere belangrijke moeilijk vergelijkbare componenten in de data tussen Japan en Europa hebben we Japan buiten de analyse gehouden.

De 11 Europese landen die aan de enquête deelnamen zijn opgesplitst in 64 regio's. Voor de meeste EU lidstaten werd hierbij de NUTS1 indeling van regio's gebruikt. Voor Zweden (dat op NUTS1-niveau als één regio wordt gezien) werd een indeling op NUTS2-niveau gebruikt. Voor de twee niet-lidstaten Noorwegen en Tsjechië werd een vergelijkbare indeling gehanteerd. In ieder land hebben tussen de twee- en drieduizend hoger opgeleiden aan de enquête deelgenomen. In een aantal gevallen bleek zich echter een zeer gering aantal schoolverlaters in een specifieke regio te bevinden. Dit doet zich uiteraard vooral voor in grote landen waar veel regio's worden onderscheiden. In dergelijke gevallen zijn in de analyse deze regio en een buurtregio samengenomen. Voor Spanje is in de enquête geen regioinformatie beschikbaar, terwijl in Finland de bevolking dermate sterk rond Helsinki is geconcentreerd dat een analyse van de twee andere regio's niet haalbaar bleek. Voor deze twee landen heeft de analyse daarom op landniveau plaatsgevonden. In Appendix A wordt een overzicht gegeven van de gehanteerde regio-indeling alsmede het aantal waarnemingen en het computergebruik onder de geënquêteerden.

De schriftelijke enquête werd toegezonden aan schoolverlaters die ongeveer drie jaar daarvoor het hoger onderwijs hadden verlaten. In de enquête worden de afgestudeerden onder andere gevraagd voor een 36-tal vaardigheden retrospectief hun vaardigheden te 
beoordelen op het moment van afstuderen. In Appendix B staat de volledige lijst van vaardigheden die hierbij werden gebruikt. Op de vraag "Geef in het schema hieronder aan de mate waarin $u$ over de volgende aspecten van kennis en vaardigheden beschikte op het moment van afstuderen in 1994/1995" konden de respondenten kiezen uit vijf antwoorden, die in het onderzoek gecodeerd zijn van (1) "helemaal niet" tot (5) "in hoge mate".

In de vragenlijst werd ook de vraag gesteld "Geef in het schema hieronder aan de mate waarin computervaardigheden worden vereist in uw huidige baan". Het computergebruik per regio werd bepaald aan de hand van het percentage werkende respondenten dat op de schaal van (1) "helemaal niet" tot (5) "in hoge mate" minstens 3 invulde ${ }^{15}$. Appendix A laat zien dat het computergebruik onder hoog opgeleide jongeren per regio varieert van 71,7 procent in Bassin Parisien en Nord-pas-de-Calais in Frankrijk tot 93,6 procent in Norra Mellansverige in Zweden. Ook in Spanje en enkele andere regio's in Frankrijk is het computergebruik relatief laag. Met name in een aantal andere regio's in Zweden en Duitsland is het computergebruik relatief hoog.

Om de waarde van de verschillende vaardigheden te bepalen, hebben we de volgende loonvergelijkingen geschat:

$$
\ln w^{\prime} \quad C \text { \%â X \%ãZ \%å. }
$$

In deze vergelijking is In w de natuurlijke logaritme van het uurloon, $C$ een constante, $X$ een vector van vaardigheden, $Z$ een vector met persoonlijke kenmerken zoals vrouw, getrouwd, tijdelijke baan en het kruiseffect van vrouw en getrouwd en å een storingsterm met de gebruikelijke veronderstellingen. â is de te schatten coëfficiënt die de waarde van de verschillende vaardigheden aangeeft. Omdat we juist willen analyseren in welke mate computerisering leidt tot verschuivingen in de waarde van vaardigheden, schrijven we â als een vergelijking waarin het computergebruik in de betreffende regio $(\mathrm{CR})$ is opgenomen. Voor elk van de 64 regio's geldt dus

$$
\text { â ' } \hat{a}_{0} \% \hat{a}_{1} C R \% \text { ç. }
$$

Zonder de storingsterm ç zou vergelijking (2) in (1) kunnen worden gesubstitueerd, en zou het model met kruiseffecten voor competentiexcomputergebruik in de regio middels OLS worden geschat. Zoals Moulton (1986) laat zien, leidt het negeren van mogelijke stochastische elementen in de parameters op regioniveau tot mogelijk zeer grote vertekeningen in de schattingsresultaten met veelal zeer misleidende test statistieken. In deze bijdrage gebruiken we daarom een random-coëfficiëntenmethode om de parameters te schatten (zie bijvoorbeeld, Swamy, 1970 en 1971). Hierbij wordt in een eerste ronde vergelijking (1) voor elk van de 64 regio's afzonderlijk geschat en worden vervolgens de schattingsresultaten per regio gebruikt als input voor het schatten van vergelijking (2). Omdat de regio's sterk in

15. Deze informatie gebruiken we in de regressievergelijking als computergebruik. Wanneer we de criteria veranderen, blijven de regressieresultaten vergelijkbaar. 
(steekproef)omvang verschillen is vergelijking (2) geschat met general least squares (GLS), waarbij het aantal waarnemingen per regio als weegfactor is gebruikt.

\section{Resultaten}

In de enquête zijn voor 36 vaardigheden gegevens beschikbaar. Omdat het aantal waarnemingen in de kleinere regio's niet voldoende groot is om meer dan 36 verklarende variabelen op te nemen in het model, hebben we een selectie gemaakt van 12 vaardigheden. Op basis van een aantal regressies met deelgroepen uit de competentielijst hebben we de vaardigheden geselecteerd die ofwel een duidelijk positief, ofwel een duidelijk negatief verband met computergebruik lijken te hebben. Deze twaalf vaardigheden zijn (in willekeurige volgorde) (1) algemene kennis, (2) interdisciplinaire kennis, (3) computervaardigheden, (4) plannen, coördineren en organiseren, (5) economisch denken, (6) probleemoplossend vermogen, (7) analytische vaardigheden, (8) leervermogen, (9) accuratesse, oog voor details, (10) mondelinge communicatievaardigheden, (11) leiderschap, en (12) de bereidheid verantwoordelijkheid te nemen. Het blijkt overigens dat de precieze selectie van vaardigheden niet veel invloed heeft op de uitkomsten. Zoals we verderop zullen bespreken, heeft alleen het al dan niet opnemen van computervaardigheden een duidelijke invloed op de gemeten effecten van andere vaardigheden. Consequentie van de gevolgde selectie is echter wel dat vaardigheden waarvoor de marktwaarde als gevolg van de opkomst van de computer niet lijkt te veranderen, ook niet in de tabel zijn opgenomen.

De resultaten van deze regressieanalyse zijn gerapporteerd in Tabel 1. De uitkomsten laten zien dat een aantal vaardigheden in waarde toenemen terwijl andere vaardigheden in waarde dalen door de opkomst van de computer. Een toenemende waarde hebben algemene kennis, plannen, coördineren en organiseren, economisch denken, analytische vaardigheden, mondelinge communicatievaardigheden en de bereidheid verantwoordelijkheid te nemen. Het belang van interdisciplinair denken, computervaardigheden, accuratesse en oog voor details en leiderschap daalt significant. De waarde van leervermogen neemt volgens de schattingen ook af maar dit effect is net niet significant. Voor probleemoplossend vermogen wordt vrijwel geen effect gevonden.

Vanuit het raamwerk in Sectie 2 verwachten we dat taken die door de computer zijn overgenomen minder worden gewaardeerd en dat taken die niet door de computer kunnen worden overgenomen of additionele taken die door de computer zijn ontstaan in waarde zijn toegenomen. Daarnaast kunnen productveranderingen, organisatieveranderingen en verschuivingen in vraag en aanbod een indirect effect hebben op de waarde van bepaalde vaardigheden.

Tabel 1

De waarde van vaardigheden die veranderen naar aanleiding van computergebruik op het werk in 11 Europese landen in 1999 


\begin{tabular}{llc}
\hline \multicolumn{1}{c}{ Vaardigheid } & Coëfficiënt $\hat{a}_{1}$ \\
\hline 1. Algemene kennis & $0,153(0,086)^{\star}$ \\
2. Interdisciplinair denken & $! 0,197(0,074)^{\star \star \star}$ \\
3. Computervaardigheden & $! 0,371(0,060)^{\star \star \star}$ \\
4. Plannen, coördineren en organiseren & $0,130(0,071)^{\star}$ \\
5. Economisch denken & $0,272(0,096)^{\star \star \star}$ \\
6. Probleemoplossend vermogen & $! 0,051(0,085)$ \\
7. Analytische vaardigheden & $0,233(0,084)^{\star \star \star}$ \\
8. Leervermogen & $! 0,121(0,075)$ \\
9. Accuratesse, oog voor details & $! 0,175(0,074)^{\star \star}$ \\
10. Mondelinge communicatievaardigheden & $0,218(0,062)^{\star \star \star}$ \\
11. Leiderschap & $! 0,510(0,109)^{\star \star \star}$ \\
12. Bereidheid verantwoordelijkheid te nemen & $0,223(0,083)^{\star \star \star}$ \\
\hline
\end{tabular}

Noot: Alle data zijn afkomstig van de CHEERS enquête. Standaard fouten staan tussen haakjes. * is significant op een 10 procent's niveau, ${ }^{* \star}$ is significant of een 5 procent's niveau en ${ }^{* \star *}$ is significant op een 1 procent's niveau. De waarde van de andere 24 vaardigheden worden niet gerapporteerd, omdat zij niet van invloed lijken te zijn in relatie tot computergebruik.

De toenemende waarde van algemene kennis, plannen, coördineren en organiseren, economisch denken en analytische vaardigheden komt waarschijnlijk voort uit het feit dat dit taken zijn die moeilijk zijn te automatiseren. Hetzelfde gaat op voor mondelinge communicatievaardigheid. Als een deel van de taken vermindert, doordat de computer het werk overneemt, komt er per saldo meer accent op deze werkzaamheden te liggen ${ }^{16}$.

Over accuratesse en oog voor details kan natuurlijk het omgekeerde worden opgemerkt. Omdat de computer juist bij uitstek geschikt is voor het uitvoeren van precisie werkzaamheden is er minder noodzaak voor een werkende om zich op dit front te onderscheiden. Als voorbeeld kunnen we refereren aan de automatische opmaakopties en spellingcontrole die elke wordprocessor ter beschikking heeft.

Het sterk dalende belang van computervaardigheden is natuurlijk ook opvallend. Gezien de sterke omvang van dit effect is hier waarschijnlijk sprake van een statistisch artefact. In eerdere studies is aangetoond dat computervaardigheden geen (noemenswaardige) waarde

16. Zie ook Levy en Murnane (1996), Bresnahan (1999) en Autor, Levy en Murnane (2001) voor soortgelijke bevindingen. Zij interpreteren vergelijkbare resultaten als complementaire vaardigheden die voor de beroepsbevolking als zodanig belangrijker gaan worden. Of dit daadwerkelijk zo is, lijkt twijfelachtig omdat elk beroep andere niet- routinematige taken heeft. 
op de arbeidsmarkt hebben ${ }^{17}$. Computergebruik is echter sterk gecorreleerd met het loon van de werknemer, omdat hogere lonen de investering in een computer eerder rendabel maken. Als mensen die een computer gebruiken zich vrij snel de bijbehorende vaardigheden eigen maken zou dit ook kunnen leiden tot een verband tussen computervaardigheid en loon. Conform de bevindingen in de tabel zou deze computer-loonpremie snel moeten dalen als de diffusie van de computer op de arbeidsmarkt doorgaat omdat ook steeds meer laagbetaalde krachten een computer krijgen. In de enquête is echter in principe gevraagd naar de computervaardigheden op het moment van afstuderen. Een mogelijke verklaring voor de cijfers zou daarom kunnen zijn dat de inschatting over capaciteiten drie jaar geleden behoorlijk vertekend wordt door de huidige capaciteiten op dit front. Een andere verklaring zou zijn dat een aanzienlijk deel van de schoolverlaters op het moment van diplomering reeds werkzaam was. Wanneer het effect van computervaardigheid inderdaad duidt op een omgekeerde causaliteit, is computervaardigheid in principe een benadering voor het salaris en kunnen ook de regressieresultaten met betrekking tot de andere vaardigheden vertekend zijn. Het blijkt echter dat als computervaardigheid uit de regressie wordt gelaten de resultaten grofweg gelijk blijven. Het enige substantiële verschil is dat de afnemende waarde van leervermogen in dat geval significant wordt.

Als de waarde van leervermogen inderdaad zou dalen met het toenemende computergebruik zou dit een opzienbarende bevinding zijn. Omdat de opkomst van ICT vaak wordt geassocieerd met de opkomst van de kenniseconomie, wordt vaak verondersteld dat levenslang leren en daarmee leervermogen in belang toeneemt. Vragen die zich hierbij voordoen zijn echter of de relatie tussen ICT en de kenniseconomie niet vooral wordt gelegd omdat de "kenniswerkers" als eerste gebruik zijn gaan maken van de mogelijkheden die ICT bood en of kenniseconomie niet veel meer betekent dat we meer kennis ter beschikking hebben zonder dat werkenden zich deze echt eigen moeten maken. Vanuit het raamwerk dat gepresenteerd is in sectie 2 ligt het in ieder geval voor de hand dat er een verschuiving plaatsvindt van de noodzaak om kennis over regels en procedures te accumuleren naar meer diepgravende analytische vaardigheden. Als kennis over specifieke regels en dergelijke met name al werkende werd geleerd, terwijl analytische vaardigheden met name tijdens een fulltime opleiding zijn verworven, zou een verschuivend belang van de initiële opleiding ten koste van het latere leren inderdaad voor de hand liggen.

In de literatuur komt steeds duidelijker naar voren dat de opkomst van de computer grote invloed heeft op de wijze waarop bedrijven zijn georganiseerd. Studies van Kremer en Maskin (1995) en Acemoglu (1999) laten zien dat technologische veranderingen binnen bedrijven steeds vaker gepaard gaan met een plattere structuur van de organisatie waarin specialisten met vergelijkbare opleidingsniveaus steeds vaker met elkaar werken in teamverband. Van brede interdisciplinaire kennis kan in zulk soort situaties dan geen sprake zijn, eerder van een combinatie van specialisten op projectmatige basis. Dit komt ook tot uitdrukking in de

17. Zie onder andere Bell (1996) en Borghans en Ter Weel (2001b) voor een empirische analyse van de waarde van computervaardigheden. Borghans en Ter Weel (2001a) werken de consequenties van deze bevinding tevens analytisch uit. 
resultaten die zijn gerapporteerd in tabel 1. Als organisaties als gevolg van de mogelijkheden van ICT inderdaad minder hiërarchisch worden en professionele communicatie en individuele of groepsverantwoordelijkheid belangrijker worden, dan is het de verwachting dat de waarde van leiderschapskwaliteiten afnemen en de bereidheid verantwoordelijkheid te nemen in waarde toeneemt.

Tabel 2

Verschil in vaardigheden tussen mensen met hoge en lage studieprestaties

\begin{tabular}{llrr}
\hline & \multicolumn{1}{c}{ Vaardigheid } & vooropleiding & opleiding \\
\hline 1. & Algemene kennis & 0,26 & 0,07 \\
2. & Interdisciplinair denken & 0,17 & 0,11 \\
3. & Computervaardigheden & 0,17 & 0,06 \\
4. & Plannen, coördineren en organiseren & 0,14 & 0,04 \\
5. & Economisch denken & 0,06 & $! 0,23$ \\
6. & Probleemoplossend vermogen & 0,24 & 0,11 \\
7. & Analytische vaardigheden & 0,31 & 0,24 \\
8. & Leervermogen & 0,40 & 0,23 \\
9. & Accuratesse, oog voor details & 0,28 & 0,21 \\
10. & Mondelinge communicatievaardigheden & 0,29 & 0,23 \\
11. & Leiderschap & 0,05 & 0,06 \\
12. & Bereidheid verantwoordelijkheid te nemen & 0,06 & 0,09 \\
\hline
\end{tabular}

Noot: Alle data zijn afkomstig van de CHEERS-enquête.

Uit de literatuur komt naar voren dat door het toenemende gebruik van computers sprake is van een verschuiving van de vraag op de arbeidsmarkt van lager naar hoger opgeleiden ${ }^{18}$. Interessant is dan ook om te kijken of de verschuiving in het belang van vaardigheden waarover hoger opgeleiden beschikken, ook gunstig werkt voor de betere studenten ten koste van de mindere studenten. In tabel 2 wordt daarom voor de 12 vaardigheden aangegeven in welke mate betere studenten over meer vaardigheden beschikken dan mindere studenten. In de eerste kolom is deze vergelijking gemaakt op basis van de rapportcijfers aan het einde van de vooropleiding, terwijl in de tweede kolom de studieprestaties tijdens de laatste opleiding zijn gebruikt om te differentiëren tussen betere en minder goede studenten.

Uit deze tabel komt geen duidelijke verschuiving in het voordeel van de betere studenten naar voren. Als we beide indicatoren in ogenschouw nemen blijkt dat met name bij analytische vaardigheden, leervermogen, accuratesse en oog voor details en bij mondelinge com-

18. Zie bijvoorbeeld Autor, Katz en Krueger (1998) en de studies genoemd in de introductie. 
municatievaardigheden het verschil tussen de betere en de minder goede student groot is. Analytische vaardigheden en mondelinge communicatievaardigheden nemen echter in belang toe, terwijl leervermogen en accuratesse en oog voor detail minder belangrijk worden.

\section{Conclusies}

Vertrekpunt voor deze bijdrage was de constatering dat er duidelijk aanwijzingen zijn dat door de sterke opmars van de computer op de arbeidsmarkt grote verschuivingen plaatsvinden in het belang van verschillende vaardigheden. Hoewel aanvankelijk vooral gekeken werd naar vaardigheden die direct nodig zijn om optimaal gebruik te kunnen maken van de mogelijkheden die een computer biedt, is de laatste tijd uit onderzoek duidelijk geworden dat de betekenis van computervaardigheden of van zogenaamde complementaire vaardigheden voor de veranderingen op de arbeidsmarkt niet zo groot is. Zowel door een verschuivend takenpakket als door veranderingen in de organisatiestructuur zou de computer echter indirect voor substantiële veranderingen in het belang van vaardigheden kunnen zorgen.

Door een vergelijking te maken van het belang van vaardigheden in regio's waar in verschillende mate het computergebruik is doorgedrongen, hebben we in deze bijdrage geanalyseerd welke vaardigheden als gevolg van computerisering in waarde toe lijken te nemen en welke in waarde lijken te dalen. Er zijn duidelijk aanwijzingen gevonden dat algemene kennis, plannen, coördineren en organiseren, economisch denken en mondelinge communicatievaardigheden door de opkomst van de computer inderdaad belangrijker zijn geworden. Interdisciplinair denken en accuratesse en oog voor details lijken in belang af te nemen. Dit past binnen de gedachte van een verschuiving in het takenpakker van hoger opgeleiden. Daarnaast lijkt het afnemend belang van leiderschap, met de toenemende waarde van de bereidheid om verantwoordelijkheid te nemen te wijzen op substantiële markteffecten van organisatorische veranderingen. Hoewel de resultaten minder duidelijk zijn dan voor de andere vaardigheden is ook het afnemend belang van leervermogen een interessante bevinding.

Hoewel veel is geschreven en gespeculeerd over de implicaties die de computer en ICT in het algemeen hebben voor het belang van verschillende vaardigheden, is er nog nauwelijks empirisch onderzoek gedaan naar de feitelijke verschuivingen die plaatsvinden. Met deze analyse hebben we hieraan een bijdrage willen leveren. De algemene trends die we in onze bijdrage op het spoor zijn gekomen betekenen echter niet dat in ieder beroep dezelfde veranderingen plaats zullen vinden: de verschuivingen voor middelbaar- of lager opgeleiden kunnen heel anders zijn. Verder onderzoek en vooral ook adequate dataverzameling zijn dus nodig om een goed beeld te krijgen van de implicaties van computers voor het werk. We denken echter dat de resultaten die zijn gepresenteerd in deze bijdrage in ieder geval duidelijk maken dat de effecten van de opkomst van de computer alleen doorgrond kunnen worden door systematische empirische analyses. 


\section{Literatuur}

Acemoglu, D. (1999), Changes in Unemployment and Wage Inequality: An Alternative Theory and Some Evidence. American Economic Review, 89(5), pp. 1259-1278.

Ahituv, A. en J. Zeira (2001), Technical progress and early retirement. Mimeo. Hebrew University, februari.

Autor, D.H., L.F. Katz en A.B. Krueger (1998), Computing Inequality: Have Computers Changed the Labor Market? Quarterly Journal of Economics, 113(4), pp. 1169-1213.

Autor, D.H., F. Levy en R.J. Murnane (2000), Upstairs, downstairs: computer-skill complementarity and computer-labor substitution on two floors of a large bank. NBER Working Paper 7890 september.

Autor, D.H., F. Levy en R.J. Murnane (2001), The skill content of recent technological change: an empirical exploration. Mimeo. MIT, januari.

Bartel, A.P. en N. Sicherman (1993), Technological Change and Retirement Decisions of Older Workers. Journal of Labor Economics, 11(1), pp. 162-183.

Bell, B.D. (1996), Skill-biased technical change and wages: evidence from a longitudinal data set. Mimeo. Nuffield College, oktober.

Berman, E., J. Bound en Z. Griliches (1994), Changes in the Demand for Skilled Labor within U.S. Manufacturing Industries. Quarterly Journal of Economics, 109(1), pp. 367-398.

Berman, E., J. Bound en S. Machin (1998), Implications of Skill-Biased Technological Change: International Evidence. Quarterly Journal of Economics, 113(4), pp. 1245-1279.

Borghans, L. en B. ter Weel (2000), Hoe computerisering de arbeidsmarkt verandert: de feiten op een rij vanuit een nieuw raamwerk. In: L. Soete (red.), ICT en de nieuwe economie: preadviezen aan de koninklijke vereniging voor de staathuishoudkunde. Utrecht: Lemma, pp. 105-132.

Borghans, L. en B. ter Weel (2001a), What happens when agent T gets a computer. MERIT Research Memorandum 2001-018, Universiteit Maastricht, mei.

Borghans, L. en B. ter Weel (2001b), Computers, skills and wages. MERIT Research Memorandum 2001-020, Universiteit Maastricht, juni.

Borghans, L. en B. ter Weel (2001c), Technologie, RenD, ICT en productiviteit. Studie in opdracht van de Organisatie voor Strategisch Arbeidsmarktonderzoek.

Borghans, L. en B. ter Weel (2001d), Computers Zijn geen Probleem voor Ouderen. Economisch Statistische Berichten, 86(4320), pp. 620-624.

Borghans, L. en B. ter Weel (2001e), Why pens changed the wage structure and computers did not: the returns to computer and writing skills revisited. Mimeo. Universiteit Maastricht University, juni.

Bresnahan, T.F. (1999), Computerisation and Wage Dispersion: An Analytical Reinterpretation. Economic Journal, 109 (Features), pp. F390-F415. 
Bresnahan, T.F., E. Brynjolfsson en L. Hitt (2001), Information Technology, Workplace Organization, and the Demand for Skilled Labor: Firm-Level Evidence. Quarterly Journal of Economics, 117(1), te verschijnen.

Caroli, E. en J. Van Reenen (2001), Skill Biased Organizational Change? Evidence from a Panel of British and French Establishments. Quarterly Journal of Economics, 116(4), pp. 1449-1492.

Chennells, L. en J. Van Reenen (1997) Technical Change and Earnings in British Establishments. Economica, 64(3), pp. 587-604.

DiNardo, J. en J.-S. Pischke (1996), The return to computer use revisited: have pencils changed the wage structure too? NBER Working Paper 5606.

DiNardo, J. en J.-S. Pischke (1997), The Return to Computer Use Revisited: Have Pencils Changed the Wage Structure too? Quarterly Journal of Economics, 112(1), pp. 291-303.

Doms, M., T. Dunne en K.R. Troske (1997), Workers, Wages and Technology. Quarterly Journal of Economics, 112(1), pp. 253-290.

Dunne, T., L. Foster, J. Haltiwanger en K.R. Troske (2000), Wage and productivity dispersion in U.S. manufacturing: the role of computer investment. NBER Working Paper 7465.

Dunne, T. en J. Schmitz (1995), Wage, Employment Structure and Employer-Size Wage Premia: Their Relationship to Advanced-Technology Usage at U.S. Manufacturing Establishments. Economica, 62(1), pp. 89-107.

EITO (2000), European information technology observatory. Frankfurt am Main: European Economic Interest Grouping.

Entorf, H. en F. Kramarz (1997), Does Unmeasured Ability Explain the Higher Wages of New Technology Workers? European Economic Review, 41(6), pp. 1489-1509.

Fernandez, R. (2001), Skill-Biased Technological Change and Wage Inequality: Evidence from a Plant Retooling. American Journal of Sociology, te verschijnen.

Freeman, C. en L. Soete (1994), Work for all or mass unemployment. London: Pinter.

Friedberg, L. (2001), The impact of technological change on older workers: evidence from data on computers. NBER Working Paper 8297.

Greenwood, J. en M. Yorukoglu (1997), 1974. Carnegie Rochester Conference Series on Public Policy, 46, pp. 49-95.

Groot, L. en A. de Grip (1991), Technological Change and Skill Formation in the Bank Sector. Economics of Education Review, 10(1), pp. 57-71.

Jorgenson, D. (2001), Information Technology and the U.S. Economy. American Economic Review, 91(1), pp. 1-32.

Katz, L.F. en D.H. Autor (1999), Changes in the wage structure and earnings inequality. In:

O. Ashenfelter en D. Card (red.), Handbook of labor economics, 3. Amsterdam: NorthHolland, pp. 1463-1555.

Kremer, M. en E. Maskin (1995), Wage inequality and segregation by skill. Mimeo. MIT, juni. 
Krueger, A.B. (1993), How Computers Have Changed the Wage Structure: Evidence from Microdata, 1984-1989. Quarterly Journal of Economics, 108(1), pp. 33-60.

Lang, K. (2001), Of pencils and computers. Mimeo. MIT, februari.

Levy, F. en R. Murnane (1996), With What Skills Are Computers Complements? American Economic Review, 86(2), pp. 258-262.

Lindbeck, A. en D.J. Snower (2000), Multitask Learning and the Reorganization of Work: From Tayloristic to Holistic Organization. Journal of Labor Economics, 18(2), pp. 353-376. Machin, S. en J. Van Reenen (1998), Technology and Changes in Skill Structure: Evidence from Seven OECD Countries. Quarterly Journal of Economics, 113(4), pp. 1216-1244.

Miller, P. en C. Mulvey (1997), Computer Skills and Wages. Australian Economic Papers, 36(2), pp. 106-113.

Moulton, B. (1986), Random Group Effects and the Precision of Regression Estimates. Journal of Econometrics, 32(2), pp. 385-397.

Smulders, P. (2000), Computergebruik op het Werk in de Europese Unie. Tijdschrift voor Arbeidsvraagstukken, 16(3), pp. 259-277.

Swamy, P. (1970), Efficient Inference in Random Coefficient Regression Models. Econometrica, 38(1), pp. 311-323.

Swamy, P. (1971), Statistical inference in random coefficient regression models. New York: Springer-Verlag.

Weinberg, B. (2001), Experience and technology adoption. Mimeo. Ohio State University, april. 


\section{Appendix A}

\begin{tabular}{|c|c|c|c|c|}
\hline Regio & Land & NUTS1 & \multicolumn{2}{|c|}{$\begin{array}{l}\mathrm{N} \% \text { computer } \\
\text { gebruik }\end{array}$} \\
\hline Baden-Württemberg & Duitsland & DE1 & 125 & 907 \\
\hline Bayern & Duitsland & DE2 & 510 & 870 \\
\hline Berlin, Brandenburg, Mecklenburg-Vorpommern & Duitsland & DE3,DE4,DE8 & 97 & 900 \\
\hline Hessen & Duitsland & DE7 & 287 & 869 \\
\hline Niedersachsen, Bremen & Duitsland & DE9, DE5 & 197 & 857 \\
\hline Nordrhein-Westfalen & Duitsland & DEA & 863 & 872 \\
\hline Rheinland-Pfalz, Saarland & Duitsland & DEB, DEC & 66 & 909 \\
\hline Sachsen & Duitsland & DED & 61 & 923 \\
\hline Sachsen-Anhalt, Thueringen & Duitsland & DEE, DEG & 80 & 835 \\
\hline Schleswig-Holstein, Hamburg & Duitsland & DEF, DE6 & 105 & 868 \\
\hline Spain & Spanje & ES & 1409 & 781 \\
\hline Ile De France & Frankrijk & FR1 & 770 & 825 \\
\hline Bassin Parisien, Nord-pas-de-Calais & Frankrijk & FR2, FR3 & 413 & 717 \\
\hline Est & Frankrijk & FR4 & 136 & 845 \\
\hline Ouest & Frankrijk & FR5 & 209 & 755 \\
\hline Sud-Ouest & Frankrijk & FR6 & 49 & 846 \\
\hline Centre-Est & Frankrijk & FR7 & 160 & 830 \\
\hline Mediterranee & Frankrijk & FR8 & 82 & 753 \\
\hline Nord Ovest & Italië & IT1 & 167 & 746 \\
\hline Lombardia & Italië & IT2 & 445 & 825 \\
\hline Nord Est & Italië & IT3 & 244 & 784 \\
\hline Emilia-Romagna & Italië & IT4 & 104 & 894 \\
\hline Centro & Italië & IT5 & 207 & 836 \\
\hline Lazio, Abruzzo-Molise & Italië & IT6, IT7 & 172 & 831 \\
\hline Campania & Italië & IT8 & 119 & 792 \\
\hline Sud & Italië & IT9 & 61 & 803 \\
\hline
\end{tabular}




\begin{tabular}{|c|c|c|c|c|}
\hline \multirow{2}{*}{$\begin{array}{l}\text { Regio } \\
\text { Sicilia, Sardegna }\end{array}$} & \multirow{2}{*}{$\begin{array}{l}\text { Land } \\
\text { Italië }\end{array}$} & \multirow{2}{*}{$\begin{array}{l}\text { NUTS1 } \\
\text { ITA, ITB }\end{array}$} & \multicolumn{2}{|c|}{$\begin{array}{l}\mathrm{N} \% \text { computer } \\
\text { gebruik }\end{array}$} \\
\hline & & & 75 & 813 \\
\hline Noord-Nederland & Nederland & NL1 & 270 & 846 \\
\hline West-Nederland & Nederland & NL3 & 894 & 863 \\
\hline Zuid-Nederland & Nederland & NL4 & 582 & 891 \\
\hline Ost-Österreich & Oostenrijk & AT1 & 781 & 882 \\
\hline West-Österreich & Oostenrijk & AT3 & 407 & 844 \\
\hline Finland & Finland & $\mathrm{FI}$ & 2058 & 897 \\
\hline Stockholm & Zweden & SE01 & 367 & 870 \\
\hline Oestra Mellansverige & Zweden & SE02 & 420 & 893 \\
\hline Sydsverige & Zweden & SE04 & 255 & 897 \\
\hline Norra Mellansverige & Zweden & SE06 & 96 & 936 \\
\hline North West (inclusief Merseyside) & Verenigd Koninkrijk & UKD & 204 & 868 \\
\hline Yorkshire \& The Humber, North East & Verenigd Koninkrijk & UKE, UKC & 126 & 914 \\
\hline East Midlands & Verenigd Koninkrijk & UKF & 124 & 908 \\
\hline West Midlands & Verenigd Koninkrijk & UKG & 144 & 882 \\
\hline Eastern & Verenigd Koninkrijk & UKH & 227 & 904 \\
\hline London & Verenigd Koninkrijk & UKI & 318 & 910 \\
\hline South East & Verenigd Koninkrijk & UKJ & 412 & 889 \\
\hline South West & Verenigd Koninkrijk & UKK & 118 & 877 \\
\hline Wales & Verenigd Koninkrijk & UKL & 59 & 853 \\
\hline Scotland & Verenigd Koninkrijk & UKM & 385 & 858 \\
\hline
\end{tabular}




\begin{tabular}{|c|c|c|c|c|}
\hline Northern Ireland & Verenigd Koninkrijk & UKN & 143 & 831 \\
\hline Regio & Land & NUTS1 & \multicolumn{2}{|c|}{$\begin{array}{l}\mathrm{N} \% \text { computer } \\
\text { gebruik }\end{array}$} \\
\hline Oslo, Akerhus & Noorwegen & N1 & 1020 & 887 \\
\hline Hedmark og Oppland & Noorwegen & N2 & 101 & 859 \\
\hline Sør-Østland & Noorwegen & N3 & 304 & 871 \\
\hline Agder og Rogaland & Noorwegen & N4 & 293 & 889 \\
\hline Vestlandet & Noorwegen & N5 & 416 & 848 \\
\hline Tøndelag & Noorwegen & N6 & 242 & 854 \\
\hline Nord-Norge & Noorwegen & N7 & 264 & 849 \\
\hline Prague & Tsjechië & $\mathrm{C} 1$ & 652 & 865 \\
\hline Bohemia (exclusief Prague) & Tsjechië & $\mathrm{C} 2$ & 529 & 875 \\
\hline Moravia & Tsjechië & C3 & 720 & 856 \\
\hline
\end{tabular}

Noot: Alle data zijn afkomstig van de CHEERS enquête. De regio's zijn aangeduid zoals in de enquête en worden gekarakteriseerd aan de hand van NUTS1 codes. N is het aantal waarnemingen. Het computergebruik is gebaseerd op de volgende vraag: "Geef in het schema hieronder aan de mate waarin computervaardigheden worden vereist in uw huidige baan". Het percentage computergebruikers per regio is bepaald door het aantal respondenten dat op een schaal van (1) "helemaal niet" tot (5) "in hoge mate" minstens 3 invulde. 


\section{Appendix B}

Lijst van vaardigheden die in de enquête zijn opgenomen

1. Algemene kennis

2. Kennis van andere vakgebieden

3. Vak specifieke theoretische kennis

4. Vak specifieke methoden en technieken

5. Beheersing van buitenlandse talen

6. Computervaardigheden

7. Kennis van complexe systemen (sociale, organisatorische, technische)

8. Plannen/coördineren/organiseren

9. Vak specifieke regels en wetten

10. Economisch denken

11. Documenteren van informatie

12. Probleemoplossend vermogen

13. Analytische en diagnostische competenties

14. Leervermogen

15. Systematische reflectie, feedback

16. Creativiteit

17. Werken onder tijdsdruk

18. Nauwkeurigheid, zorgvuldigheid

19. Tijdsplanning

20. Onderhandelingsvaardigheden

21. Fysieke conditie

22. Handvaardigheden

23. Zelfstandigheid

24. Samenwerken, werken in teamverband

25. Initiatief

26. Aanpassingsvermogen

27. Assertiviteit, besluitvaardigheid, doorzettingsvermogen

28. Concentratie

29. Persoonlijke betrokkenheid

30. Loyaliteit, integriteit

31. Kritisch denken

32. Mondelinge presentatie/spreekvaardigheid

33. Schriftelijke presentatie/ schrijfvaardigheid

34. Tolerantie, begrip voor andere standpunten

35. Leidinggeven

36. Bereidheid verantwoordelijkheid te dragen

Noot: Alle data zijn afkomstig van de CHEERS enquête. 
